\section{Response of Hot Pepper Yield, Fruit Quality, and Fruit Ion Content to Irrigation Water Salinity and Leaching Fractions}

\author{
Rangjian Qiu', Yuanshu Jing, Chunwei Liu, and Zaiqiang Yang \\ Collaborative Innovation Center on Forecast and Evaluation of \\ Meteorological Disasters, Jiangsu Key Laboratory of Agricultural Meteorology, \\ Nanjing University of Information Science and Technology, Nanjing 210044, \\ China
}

\section{Zhenchang Wang \\ College of Water Conservancy and Hydropower Engineering, Hohai University, Nanjing 210098, China}

Additional index words. Total soluble solids, $\mathrm{Na}^{+}$concentration, water stress caused by salinity, water use efficiency, Capsicum annuum

Abstract. It has been proved that irrigation with high saline water and leaching fraction (LF) affect crop yield, but the effects of irrigation water salinity $\left(\mathrm{EC}_{\mathrm{iw}}\right)$ and $\mathrm{LF}$ on fruit quality remain largely elusive. We therefore investigated the effects of $\mathrm{EC}_{\mathrm{iw}}$ and $\mathrm{LF}$ on the yield, fruit quality, and ion content of hot peppers. An experiment using irrigation water with five levels of salinity $\left(\mathrm{EC}_{\mathrm{iw}}\right.$ of $0.9,1.6,2.7,4.7$, and $\left.7.0 \mathrm{dS} \cdot \mathrm{m}^{-1}\right)$ and two LFs $(0.17$ and 0.29$)$ was conducted in a rain shelter. The experiment took the form of a completely randomized block design, and each treatment was replicated four times. We increased the salinity of the irrigation water by adding 1:1 milliequivalent concentrations of $\mathrm{NaCl}$ and $\mathrm{CaCl}_{2}$ to a half-strength Hoagland solution. The plants were irrigated for $120 \%$ and $140 \%$ evapotranspiration, corresponding to an LF of 0.17 and 0.29 . Results showed that the total fruit yield decreased significantly with an increase in the $\mathbf{E C}_{\mathbf{i w}}$ as a result of reduction both in the fresh weight of fruit and the number of fruit per plant. An increase in the $\mathrm{EC}_{\mathrm{iw}}$ also led to a decrease in the total dry biomass of fruit and plant, as well as decreasing water use efficiency $\left(W U E_{F}\right)$. Salinity reduced the appearance of the fruit by both decreasing the length $\left(F_{L}\right)$ and maximum width $\left(F_{M W}\right)$ of the fruit. However, increased $\mathrm{EC}_{\mathrm{iw}}$ also improved the taste of the hot peppers by increasing the total soluble solid (TSS) content, as well as adding to their nutritional quality with a higher content of Vitamin C (VC). Their storage quality was also improved because of an improvement in the firmness of the fruit $\left(F_{n}\right)$ as well as a reduction in the fruit water content $\left(F_{W C}\right)$. An increase in the $L F$ led to an increase in the total fruit yield, total dry biomass of fruit and plant, and $\mathrm{WUE}_{\mathrm{F}}$; it also increased the $\mathrm{F}_{\mathrm{WC}}$ and $\mathrm{VC}$ content, and decreased the $F_{M W}$ and fruit shape index $\left(F_{S I}\right)$. The threshold-slope linear response and sigmoidal-sharp models were both a good fit for the measured total fruit yield, and the LF had no significant effect on the model parameters. The relative TSS and $F_{n}$ increased linearly as the electrical conductivity $(\mathrm{EC})$ of soil-saturated paste extract $\left(\mathrm{EC}_{\mathrm{e}}\right)$ increased, whereas they decreased linearly as the relative seasonal evapotranspiration $\left(E_{\mathbf{r}}\right)$ increased regardless of the $L F s$. The relative $F_{W}, F_{L}$, and $F_{M W}$ decreased linearly with the increased $\mathrm{EC}_{\mathrm{e}}$, and increased linearly with the increased $\mathrm{ET}_{\mathrm{r}}$ regardless of the $\mathrm{LFs}$. The relative fruit $\mathrm{Na}^{+}$concentration increased linearly as the $\mathbf{E C}_{e}$ increased. The regression correlations between the total fruit yield, fruit quality parameters, ion contents, and $\mathrm{EC}_{\mathrm{e}}$ or $E \mathrm{~T}_{\mathrm{r}}$ could provide important information for salinity and irrigation water management with a compromise between the hot pepper yield and fruit quality.

In many parts of the world, saline water collected from field drainage has been successfully used for irrigation (Grattan et al., 1994). However, plants may suffer from osmotic stress, ionic imbalance, and the inhibition of nutrient absorption when irrigated with saline water, with an adverse effect on fruit yield (Ben-Gal et al., 2008; Munns, 2002). To alleviate the effects of salinity stress on plants, the application of extra water for the leaching of salts (e.g., $\mathrm{Na}^{+}, \mathrm{Ca}^{2+}$, and $\mathrm{Mg}^{2+}$ ) from the root zone is a common

method of reducing the salt content in the surface soil (Chen et al., 2016). An appropriate LF will maintain tolerable root-zone salinity (Dudley et al., 2008), in turn, enhancing the fruit yield.

Peppers (Capsicum annuum L.) are considered moderately sensitive to salt stress (Rameshwaran et al., 2016). The thresholdslope linear response model (Maas and Hoffman, 1977) and the sigmoidal-sharp salinity response model (Van Genuchten and Hoffman, 1984) are commonly used to describe yield-salinity relationship. The LF may affect the yield of peppers, but whether the LF also has an effect on the parameters of these models is unclear.

Irrigation with saline water may in many cases improve fruit quality. The fruit quality parameters of tomatoes (Solanum lycopersicum L.) including total acidity, TSS, sugar content, pigment content, and organic acid content were improved by saline water irrigation (Gough and Hobson, 2015; Plaut and Yehezkel, 2004). It also improved the quality of the melons (Citrullus vulgaris L.) by increasing $\mathrm{F}_{\mathrm{n}}$, dry matter, acidity, TSS, and total sugar content (Colla et al., 2006; Navarro et al., 1999). For peppers, however, there is limited literature that is mainly concerned with sweet peppers or bell peppers, and it is not inconclusive. Navarro et al. (2010) and Rubio et al. (2009) found that irrigation with saline water $\left(3.0 \mathrm{dS} \cdot \mathrm{m}^{-1} \mathrm{NaCl}\right)$ had no effect on the TSS, $\mathrm{F}_{\mathrm{n}}$, and, $\mathrm{pH}$ of sweet peppers. However, Navarro et al. (2002) found that saline water irrigation (from $\mathrm{NaCl}$ or $\mathrm{Na}_{2}$ $\mathrm{SO}_{4}$ ) decreased the quality of sweet peppers by reducing pulp thickness, $F_{n}$, TSS, and fructose, glucose, and amino acid contents. On the other hand, saline water irrigation improved the fruit quality of bell peppers giving higher TSS, VC content (ascorbic acid), total sugar content, and acidity (Patil et al., 2014), and improved the quality of sweet peppers causing a higher myoinositol, fructose, and glucose content (Rubio et al., 2009). The quantitative relationship between the fruit quality parameters of hot peppers and the $\mathrm{EC}_{\mathrm{e}}$ or evapotranspiration, which are useful relationship to know for the management of saline irrigation for high-quality hot pepper production, have not been documented. In addition, we studied $\mathrm{Na}^{+}, \mathrm{K}^{+}$, and $\mathrm{Ca}^{2+}$ concentrations and $\mathrm{K}^{+} / \mathrm{Na}^{+}$ratio in hot peppers to further understand the mechanisms causing the effects of the $\mathrm{EC}_{\mathrm{iw}}$ and $\mathrm{LF}$ on yield and quality.

The objectives of this study are 1) to assess the effects of $\mathrm{EC}_{\mathrm{iw}}$ and $\mathrm{LF}$ on the yield, fruit quality, and ion content of hot peppers; 2) to study the responses of a total yield of hot peppers to salinity and to calibrate the yield indices of both a threshold-slope linear response model and sigmoidal-shape model; and 3) to establish the quantitative relationships between fruit quality, ion content, and $\mathrm{EC}_{\mathrm{e}}$ or seasonal evapotranspiration.

\section{Materials and Methods}

Experimental setup. The experiment was conducted from Apr. 28 to July 22, 2015, in a rain shelter at the Agro-Meteorology Research Station in Nanjing City, Jiangsu Province, China. The white plastic pots (top diameter $26 \mathrm{~cm} \times$ bottom diameter $22 \mathrm{~cm} \times$ height $27 \mathrm{~cm}$ ), with a $2-\mathrm{cm}$ hole in the bottom of each pot to allow for drainage were used. Each pot was filled with $11 \mathrm{~kg}$ of air-dried soil with a sandy loam texture sifted through a $5-\mathrm{mm}$ sieve. The bulk density of the soil was $1.47 \mathrm{~g} \cdot \mathrm{cm}^{-3}$, the field water capacity was 
Table 1. Effects of irrigation water salinity $\left(\mathrm{EC}_{\mathrm{iw}}\right)$ and leaching fraction (LF) on yield parameters and water use efficiency (WUE $\mathrm{F}_{\mathrm{F}}$ of hot pepper using two-way analysis of variance (ANOVA).

\begin{tabular}{|c|c|c|c|c|c|c|}
\hline Factors & $\begin{array}{l}\text { Number of fruits } \\
\text { per plant }\end{array}$ & Fresh fruit wt $(\mathrm{g})$ & $\begin{array}{c}\text { Total fruit } \\
\text { yield (g/plant) }\end{array}$ & $\begin{array}{c}\text { Total fruit dry } \\
\text { biomass ( } \mathrm{g} / \text { plant })\end{array}$ & $\begin{array}{c}\text { Plant dry } \\
\text { biomass (g/plant) }\end{array}$ & WUE $_{\mathrm{F}}\left(\mathrm{kg} \cdot \mathrm{m}^{-3}\right)$ \\
\hline 0.9 & $23.5 \mathrm{a}$ & $28.2 \mathrm{a}$ & $656.1 \mathrm{a}$ & $48.5 \mathrm{a}$ & $88.0 \mathrm{a}$ & $26.1 \mathrm{a}$ \\
\hline 1.6 & $21.0 \mathrm{ab}$ & $27.9 \mathrm{a}$ & $577.7 \mathrm{~b}$ & $42.6 \mathrm{~b}$ & $80.5 \mathrm{~b}$ & $23.4 \mathrm{~b}$ \\
\hline 4.7 & $17.8 \mathrm{~b}$ & $21.8 \mathrm{c}$ & $385.3 \mathrm{~d}$ & $36.3 \mathrm{c}$ & $62.6 \mathrm{~d}$ & $20.6 \mathrm{c}$ \\
\hline 7.0 & $13.6 \mathrm{c}$ & $19.1 \mathrm{c}$ & $257.3 \mathrm{e}$ & $25.9 \mathrm{~d}$ & $44.1 \mathrm{e}$ & $15.4 \mathrm{~d}$ \\
\hline \multicolumn{7}{|l|}{ LF } \\
\hline \multicolumn{7}{|l|}{ ANOVA } \\
\hline LF & NS & NS & $*$ & $*$ & $*$ & $*$ \\
\hline $\mathrm{EC}_{\mathrm{iw}}$ & $* * *$ & $* * *$ & $* * *$ & $* * *$ & $* * *$ & $* * *$ \\
\hline $\mathrm{EC}_{\mathrm{iw}} \times \mathrm{LF}$ & NS & NS & NS & NS & NS & NS \\
\hline
\end{tabular}

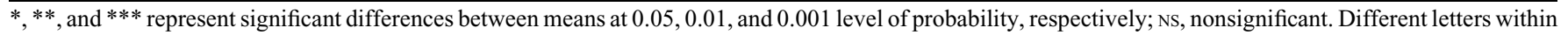
a column for each experimental factor indicate significant difference at $P<0.05$ by Duncan's multiple range tests.

$0.27\left(\mathrm{~cm}^{3} \cdot \mathrm{cm}^{-3}\right)$, the wilting point was $0.04\left(\mathrm{~cm}^{3} \cdot \mathrm{cm}^{-3}\right)$, and the soil $\mathrm{pH}$ was 7.4 . The available $\mathrm{N}, \mathrm{P}$, and $\mathrm{K}$ contents of the soil were $28.0,16.3$, and $47.7 \mathrm{mg} \cdot \mathrm{kg}^{-1}$, respectively, and soil organic matter content was $7.3 \mathrm{~g} \cdot \mathrm{kg}^{-1}$.

Hot pepper plants (cultivar Bocuiwang) of a similar height were selected and transplanted into plastic pots on Apr. 28, 2015, one plant per pot. Before transplanting, all the pots were saturated with tap water. Each plant was irrigated using tap water at $5 \mathrm{~d}$ after transplanting (DAT) with an irrigation amount of $0.9 \mathrm{~L}$ per plant. Saline water treatments with two LFs commenced 10 DAT.

Irrigation water with five levels of salinity (i.e., $0.9,1.6,2.7,4.7$, and $7.0 \mathrm{dS} \cdot \mathrm{m}^{-1}$ ) and two LFs (i.e., 0.17 and 0.29 ) was included in the experiment. The experiment was a completely randomized block design comprising 10 treatments with each treatment being replicated four times. A half strength Hoagland solution [in mmol. $\mathrm{L}^{-1}: 2.0 \mathrm{Ca}\left(\mathrm{NO}_{3}\right)_{2} \times 4 \mathrm{H}_{2} \mathrm{O}$, $2.0 \mathrm{KNO}_{3}, 0.5 \mathrm{NH}_{4} \mathrm{NO}_{3}, 0.5 \mathrm{MgSO}_{4} \times 7 \mathrm{H}_{2} \mathrm{O}$, $0.25 \mathrm{KH}_{2} \mathrm{PO}_{4}$; in $\mu \mathrm{mol} \cdot \mathrm{L}^{-1}$ : $40 \mathrm{Fe}-\mathrm{EDTA}, 25$ $\mathrm{H}_{3} \mathrm{BO}_{3}, 2.0 \mathrm{MnCl}_{2} \times 4 \mathrm{H}_{2} \mathrm{O}, 2.0 \mathrm{ZnSO}_{4} \times$ $7 \mathrm{H}_{2} \mathrm{O}, 0.5 \mathrm{CuSO}_{4} \times 5 \mathrm{H}_{2} \mathrm{O}, 50 \mathrm{KCl}, 0.075$ $\left.\left(\mathrm{NH}_{4}\right)_{6} \mathrm{Mo}_{7} \mathrm{O}_{24} \times 4 \mathrm{H}_{2} \mathrm{O}, 0.15 \mathrm{CoCl}_{2} \times 6 \mathrm{H}_{2} \mathrm{O}\right]$ at $\mathrm{EC}$ of $0.9 \mathrm{dS} \cdot \mathrm{m}^{-1}$ was added to the irrigation water that was used as a nonsaline treatment (Heeg et al., 2008). Saline water was produced by adding 1:1 milliequivalent

Received for publication 25 Apr. 2017. Accepted for publication 25 May 2017.

We are grateful for the research grants from the National Natural Science Foundation of China (51509130, 41575111, 41475107, 51309080), the Natural Science Foundation of Jiangsu Province (BK20150908), the National Science and Technology Support Program during the Twelfth Five-Year Plan (2014BAD10B07), the Jiangsu Key Laboratory of Agricultural Meteorology Foundation (JKLAM1601), and the Priority Academic Program Development of Jiangsu Higher Education Institutions (PAPD). We also thank Jinqin $\mathrm{Xu}$, Jun Chen, Shanshan Cheng, Xu Liu, and Hongzhou Chen for their assistance in this experiment.

${ }^{1}$ Corresponding author. E-mail: qiurj@nuist.edu.cn or qiurangjian@tom.com.

Table 2. Effects of irrigation water salinity $\left(\mathrm{EC}_{\mathrm{iw}}\right)$ and leaching fraction (LF) on total soluble solids (TSS), Vitamin $C$ content $(\mathrm{VC})$, fruit firmness $\left(\mathrm{F}_{\mathrm{n}}\right)$, fruit water content $\left(\mathrm{F}_{\mathrm{WC}}\right)$, fruit length $\left(\mathrm{F}_{\mathrm{L}}\right)$, maximum fruit width $\left(\mathrm{F}_{\mathrm{MW}}\right)$, and fruit shape index $\left(\mathrm{F}_{\mathrm{SI}}\right)$ of hot pepper using the two-way analysis of variance (ANOVA).

\begin{tabular}{|c|c|c|c|c|c|c|c|}
\hline Factors & TSS (\%) & $\mathrm{VC}(\mathrm{mg} / 100 \mathrm{~g} \mathrm{FW})$ & $F_{n}\left(\mathrm{~kg} \cdot \mathrm{cm}^{-2}\right)$ & $\mathrm{F}_{\mathrm{WC}}(\%)$ & $\mathrm{F}_{\mathrm{L}}(\mathrm{mm})$ & $\mathrm{F}_{\mathrm{MW}}(\mathrm{mm})$ & $\mathrm{F}_{\mathrm{SI}}$ \\
\hline \multicolumn{8}{|c|}{$\mathrm{EC}_{\mathrm{iw}}\left(\mathrm{dS} \cdot \mathrm{m}^{-1}\right)$} \\
\hline 0.9 & $3.4 \mathrm{~d}$ & $64.0 \mathrm{~b}$ & $14.4 \mathrm{c}$ & $92.83 \mathrm{a}$ & $95.7 \mathrm{a}$ & $36.3 \mathrm{ab}$ & $0.383 \mathrm{~b}$ \\
\hline 1.6 & $3.5 \mathrm{~cd}$ & $80.2 \mathrm{ab}$ & $15.0 \mathrm{bc}$ & $92.31 \mathrm{~b}$ & $93.0 \mathrm{a}$ & $36.3 \mathrm{ab}$ & $0.395 \mathrm{~b}$ \\
\hline 2.7 & $3.7 \mathrm{c}$ & $76.7 \mathrm{ab}$ & $15.7 \mathrm{~b}$ & $91.38 \mathrm{c}$ & $87.7 \mathrm{~b}$ & $37.2 \mathrm{a}$ & $0.430 \mathrm{a}$ \\
\hline 4.7 & $4.1 \mathrm{~b}$ & $74.0 \mathrm{ab}$ & $16.8 \mathrm{a}$ & $90.44 \mathrm{~d}$ & $83.0 \mathrm{c}$ & $34.9 \mathrm{bc}$ & $0.433 \mathrm{a}$ \\
\hline 7.0 & $4.5 \mathrm{a}$ & $95.1 \mathrm{a}$ & $17.6 \mathrm{a}$ & $89.87 \mathrm{e}$ & $81.3 \mathrm{c}$ & $33.7 \mathrm{c}$ & $0.421 \mathrm{a}$ \\
\hline \multicolumn{8}{|l|}{ LF } \\
\hline 0.17 & 3.9 & $65.3 \mathrm{~b}$ & 15.5 & $91.57 \mathrm{~b}$ & 88.2 & $36.4 \mathrm{a}$ & $0.423 \mathrm{a}$ \\
\hline 0.29 & 3.7 & $88.9 \mathrm{a}$ & 15.6 & $91.91 \mathrm{a}$ & 90.2 & $35.5 \mathrm{~b}$ & $0.398 \mathrm{~b}$ \\
\hline \multicolumn{8}{|l|}{ ANOVA } \\
\hline LF & NS & ** & NS & * & NS & * & $* *$ \\
\hline $\mathrm{EC}_{\mathrm{iw}}$ & $* * *$ & $*$ & $* * *$ & $* * *$ & $* * *$ & $* * *$ & $* * *$ \\
\hline $\mathrm{EC}_{\mathrm{iw}} \times \mathrm{LF}$ & NS & NS & NS & NS & $*$ & NS & $* *$ \\
\hline
\end{tabular}

$*^{* * *}$, and $* * *$ represent significant differences between means at $0.05,0.01$, and 0.001 level of probability, respectively; Ns, nonsignificant. Different letters within a column for each experimental factor indicate significant difference at $P<0.05$ by Duncan's multiple range tests.

concentrations of $\mathrm{NaCl}$ and $\mathrm{CaCl}_{2}$ to the half strength Hoagland solution.

The amount of saline irrigation water applied was $120 \%$ and $140 \%$ of evapotranspiration (ET, g), corresponding to an LF of 0.17 and 0.29 . The ET of each pot was determined by using the water balance method:

$$
\mathrm{ET}=W_{n}-W_{n+1}+(I-D) \times \rho
$$

where $W_{n}$ and $W_{n+1}$ are the pot weights before the $n$th and $(n+1)$ th irrigation $(\mathrm{g}), I$ and $D$ are the amounts of irrigation and drainage water applied, respectively (L), and $\rho$ is the water bulk density $\left(1000 \mathrm{~g} \cdot \mathrm{L}^{-1}\right)$.

A glass bottle was placed underneath each pot to collect the drainage water, and the amount collected was measured after each irrigation event. Immediately before each irrigation event, each pot was weighed, and the ET and irrigation amounts were calculated. Throughout the experiment, the irrigation interval was $2-5 \mathrm{~d}$, and in total, there were 24 irrigations.

\section{Measurements and method}

Yield, dry biomass, and $W U E_{F}$. The hot pepper fruits were harvested during their whole growth stages five times in total, starting on 8 June 2015. The weight of each fruit and the number of fruits per plant were measured at each harvesting to evaluate the mean weight of the fresh fruit and the total fruit yield. The fruit gathered at each harvesting was then dried in an oven at $70{ }^{\circ} \mathrm{C}$ to obtain a constant dry weight. The same procedure was performed at the end of the experiment on the roots, stems, and leaves of each plant. $\mathrm{WUE}_{\mathrm{F}}$ was calculated as the ratio between the total fruit yield and the seasonal ET.

Fruit quality parameters. The fruit quality parameters were measured during the fruit maturation and harvesting stages. The TSS of the hot peppers was measured using a handheld refractometer (WZ-108; Beijing Wancheng Beizen Precise Instruments Co., Ltd., China). The $F_{n}$ was detected using a fruit firmness tester (GY-3; Sanhe Instruments Co., Ltd., China) and applying a cylindrical probe to the fruit shoulder. The content of VC was determined using the 2, 6-dichloroindophenol titrimetric method (AOAC, 1984). The water content of the fruit $\left(\mathrm{F}_{\mathrm{WC}}\right)$ was determined using the oven-drying method described previously at each harvesting. The $F_{L}$ and $F_{M w}$ of each fruit were also measured using a digital vernier caliper (PD 151; Prokit's Industries Co., China), 
Table 3. Effects of irrigation water salinity $\left(\mathrm{EC}_{\mathrm{iw}}\right)$ and leaching fraction $(\mathrm{LF})$ on ion content of hot peppers using the two-way analysis of variance (ANOVA).

\begin{tabular}{lcccc}
\hline Factors & $\mathrm{Ca}^{2+}\left(\mathrm{mg} \cdot \mathrm{g}^{-1} \mathrm{DW}\right)$ & $\mathrm{K}^{+}\left(\mathrm{mg} \cdot \mathrm{g}^{-1} \mathrm{DW}\right)$ & $\mathrm{Na}^{+}\left(\mathrm{mg} \cdot \mathrm{g}^{-1} \mathrm{DW}\right)$ & $\mathrm{K}^{+} / \mathrm{Na}^{+}$ \\
\hline $\mathrm{EC}_{\mathrm{iw}}\left(\mathrm{dS} \cdot \mathrm{m}^{-1}\right)$ & & & & \\
0.9 & 1.48 & 20.80 & $0.114 \mathrm{c}$ & $192.56 \mathrm{a}$ \\
1.6 & 1.31 & 22.25 & $0.143 \mathrm{c}$ & $146.48 \mathrm{~b}$ \\
2.7 & 1.37 & 21.75 & $0.266 \mathrm{bc}$ & $97.55 \mathrm{c}$ \\
4.7 & 1.28 & 21.11 & $0.303 \mathrm{~b}$ & $72.87 \mathrm{~cd}$ \\
7.0 & 1.75 & 21.61 & $0.585 \mathrm{a}$ & $39.80 \mathrm{~d}$ \\
$\mathrm{LF}$ & & & & \\
0.17 & 1.44 & 21.7 & 0.27 & 110.58 \\
0.29 & 1.45 & 21.4 & 0.29 & 104.80 \\
$\mathrm{ANOVA}$ & & & & \\
$\mathrm{LF}$ & $\mathrm{NS}$ & $\mathrm{NS}$ & $\mathrm{NS}$ & $\mathrm{NS}$ \\
$\mathrm{EC}_{\mathrm{iw}}$ & $\mathrm{NS}$ & $\mathrm{NS}$ & $* * *$ & $* * *$ \\
$\mathrm{EC}_{\mathrm{iw}} \times \mathrm{LF}$ & $\mathrm{NS}$ & $\mathrm{NS}$ & $\mathrm{NS}$ & $\mathrm{NS}$ \\
\hline
\end{tabular}

*** represents significant differences between means at 0.001 level of probability; Ns, nonsignificant. Different letters within a column for each experimental factor indicate significant difference at $P<0.05$ by Duncan's multiple range tests.
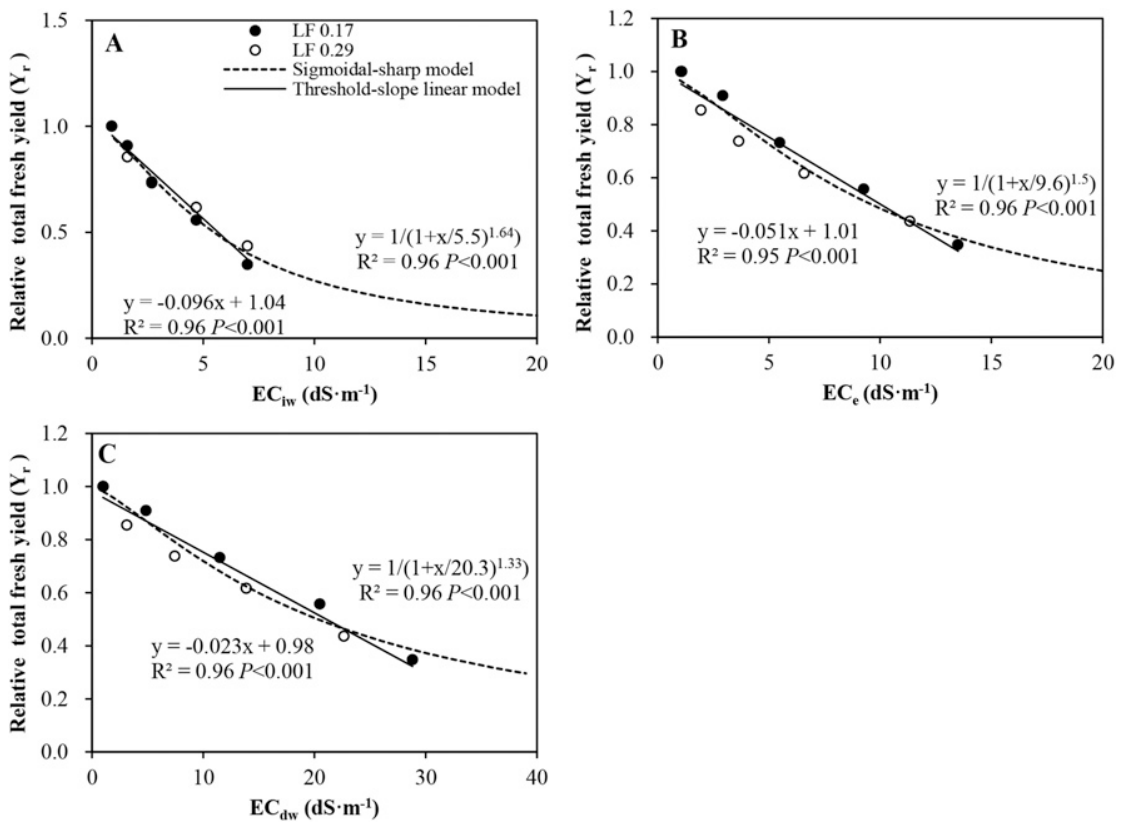

Fig. 1. Calculated threshold-shape linear response salinity model and sigmoidal-shape salinity response model based on irrigation water salinity $\left(\mathrm{EC}_{\mathrm{iw}}, \mathrm{A}\right), \mathrm{EC}$ of soil saturated paster extract $\left(\mathrm{EC}_{\mathrm{e}}, \mathrm{B}\right)$ and drainage water salinity $\left(\mathrm{EC}_{\mathrm{dw}}, \mathrm{C}\right)$ regardless of the leaching fractions $(\mathrm{LFs})$; the values of $\mathrm{EC}_{\mathrm{dw}}$ and $\mathrm{EC}_{\mathrm{e}}$ that are used were measured at the end of the experiment.

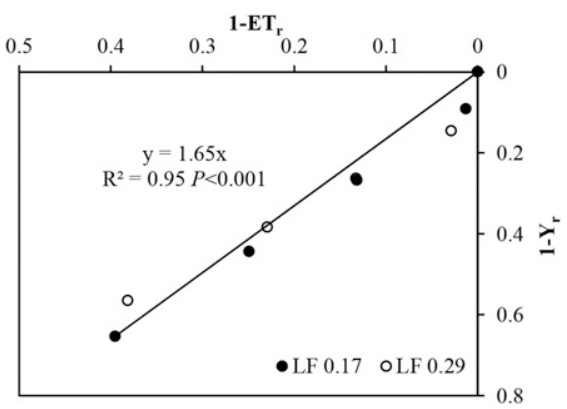

Fig. 2. Relationship between the relative total fruit yield $\left(\mathrm{Y}_{\mathrm{r}}\right)$ and relative seasonal evapotranspiration $\left(\mathrm{ET}_{\mathrm{r}}\right)$; $\mathrm{LF}$ is the leaching fraction.

and the $\mathrm{F}_{\mathrm{SI}}$ that is defined as the ratio of $\mathrm{F}_{\mathrm{MW}}$ to $\mathrm{F}_{\mathrm{L}}$ was calculated.

The $\mathrm{Na}^{+}, \mathrm{K}^{+}$, and $\mathrm{Ca}^{2+}$ content of the hot peppers. The dried fruits were mixed and then ground into powder and stored at room

$Y_{i}$ is the observed total fruit yield for the saline treatment; $\mathrm{EC}_{\mathrm{t}}\left(\mathrm{dS} \cdot \mathrm{m}^{-1}\right)$ is the threshold $\mathrm{EC}$, and $b\left(\mathrm{~m} \cdot \mathrm{dS}^{-1}\right)$ is the slope parameter, indicating the yield loss per unit increase in the $\mathrm{EC}_{\mathrm{e}}$ beyond the threshold value; $\mathrm{EC}_{\mathrm{o}}$ is the root-zone salinity above which the yield is zero.

Another model was the sigmoidal-sharp salinity response model proposed by Van Genuchten and Hoffman (1984):

$$
Y_{\mathrm{r}}=\frac{1}{1+\left(E C_{\mathrm{e}} / E C_{\mathrm{e} 50}\right)^{s}}
$$

where $\mathrm{EC}_{\mathrm{e} 50}$ represents the $\mathrm{EC}_{\mathrm{e}}$ value when $\mathrm{Y}_{\mathrm{r}}=0.5$; and $s$ is a dimensionless empirical parameter.

We applied these two models to analyze the effect of salinity on the $\mathrm{Y}_{\mathrm{r}}$. We also used $\mathrm{EC}_{\mathrm{iw}}$ and drainage water salinity $\left(\mathrm{EC}_{\mathrm{dw}}\right)$ instead of $\mathrm{EC}_{\mathrm{e}}$ in Eqs. [2] and [3] to assess the effects of $\mathrm{EC}_{\mathrm{iw}}$ and $\mathrm{EC}_{\mathrm{dw}}$ on the $\mathrm{Y}_{\mathrm{r}}$.

Water stress caused by salinity. Stewart and Hagan (1973) proposed a model to predict the yield from ET. The publication FAO 33 introduced a relationship between the relative yield decrease for water stress combining a yield response factor $\left(\mathrm{K}_{\mathrm{y}}\right)$ and relative seasonal $\mathrm{ET}\left(\mathrm{ET}_{\mathrm{r}}=\mathrm{ET}_{\mathrm{i}} / \mathrm{ET}_{\mathrm{m}}\right.$, where $\mathrm{ET}_{\mathrm{i}}$ and $\mathrm{ET}_{\mathrm{m}}$ are observed seasonal ET values for saline treatments and maximum ET, respectively) to assess plant tolerance to water stress (Doorenbos and Kassam, 1979). This model has already been used to analyze salinity in many previous studies (Heidarpour et al., 2009; Kiremit and Arslan, 2016) and was used in this study:

$$
1-Y_{\mathrm{r}}=K_{\mathrm{y}}\left(1-E T_{\mathrm{r}}\right)
$$

Statistical analysis. SPSS (Version 21.0; IBM Corp., Armonk, NY) was used to give two-way analyses of variance using the general linear model-univariate procedure to determine the effects of the $\mathrm{EC}_{\mathrm{iw}}$ and $\mathrm{LF}$ on the following characteristics of the hot peppers: number of fruit per plant; fresh fruit weight; total fruit yield; total fruit dry biomass; plant dry biomass; $\mathrm{WUE}_{\mathrm{F}}$; TSS; VC; $\mathrm{F}_{\mathrm{n}} ; \mathrm{F}_{\mathrm{WC}} ; \mathrm{F}_{\mathrm{L}} ; \mathrm{F}_{\mathrm{MW}} ; \mathrm{F}_{\mathrm{SI}}$; and the $\mathrm{Na}^{+}, \mathrm{K}^{+}$, and $\mathrm{Ca}^{2+}$ concentrations and $\mathrm{K}^{+} / \mathrm{Na}^{+}$ratios of hot peppers. The correlations between hot pepper fruit quality parameters, ion contents, and ET or $\mathrm{EC}_{\mathrm{e}}$ were analyzed by linear regression, as were the relationship between relative yield and relative seasonal ET, and the yield response function proposed by Maas and Hoffman (1977). The yield response function suggested by Van Genuchten and Hoffman (1984) was analyzed using nonlinear regression in SPSS.

\section{Results} fitted to the yield reduction models. One was the threshold-slope linear response model proposed by Maas and Hoffman (1977):

$Y_{\mathrm{r}}=\frac{Y_{\mathrm{i}}}{Y_{\mathrm{m}}}= \begin{cases}1 & 0 \leq E C_{\mathrm{e}} \leq E C_{\mathrm{t}} \\ 1-b\left(E C_{\mathrm{e}}-E C_{\mathrm{t}}\right) & E C_{\mathrm{t}}<E C_{\mathrm{e}}<E C_{\mathrm{o}} \\ 0 & E C_{\mathrm{e}}>E C_{\mathrm{o}}\end{cases}$

where $\mathrm{Y}_{\mathrm{m}}$ is the maximum total fruit yield, mainly represented by an $\mathrm{EC}_{\mathrm{iw}}$ of $0.9 \mathrm{dS} \cdot \mathrm{m}^{-1}$; 


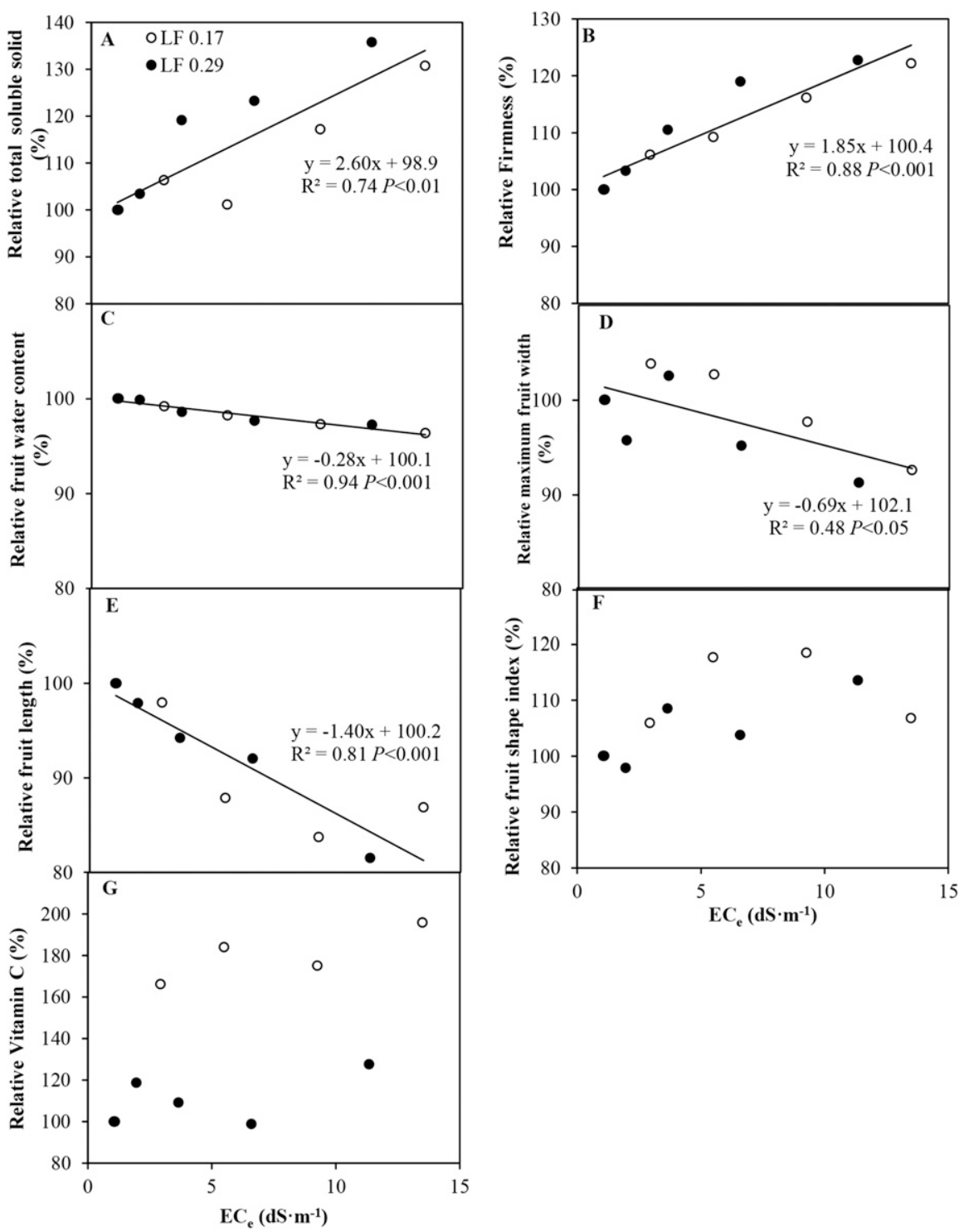

Fig. 3. Relationships between relative fruit quality parameters [total soluble solid (A); firmness (B); fruit water content $(\mathbf{C})$; maximum fruit width (D); fruit length $(\mathbf{E})$; fruit sharp index $(\mathbf{F})$ and Vitamin $\mathbf{C}(\mathbf{G})]$ and $\mathrm{EC}$ of soil saturated paste extract $\left(\mathrm{EC}_{\mathrm{e}}\right)$ regardless of the leaching fractions (LFs).

yield decreased by $12.0 \%$ to $60.8 \%$ in the $\mathrm{EC}_{\mathrm{iw}}$ of $1.6-7.0 \mathrm{dS} \cdot \mathrm{m}^{-1}$, compared with the $\mathrm{EC}_{\mathrm{iw}}$ of $0.9 \mathrm{dS} \cdot \mathrm{m}^{-1}$.

The dry biomass of both the fruit and plants decreased significantly with an increase in the $\mathrm{EC}_{\mathrm{iw}}$, with the highest values obtained from the $\mathrm{EC}_{\mathrm{iw}}$ of $0.9 \mathrm{dS} \cdot \mathrm{m}^{-1}$ and the lowest from the $\mathrm{EC}_{\mathrm{iw}}$ of $7.0 \mathrm{dS} \cdot \mathrm{m}^{-1}$. The $\mathrm{EC}_{\mathrm{iw}}$ led to a reduction of $10.3 \%$ to $41.0 \%$ in $\mathrm{WUE}_{\mathrm{F}}$ when the plants were subjected to the $\mathrm{EC}_{\mathrm{iw}}$ of $1.6-7.0 \mathrm{dS} \cdot \mathrm{m}^{-1}$.

Across the different $\mathrm{EC}_{\mathrm{iw}}$, a high $\mathrm{LF}$ significantly increased the total fruit yield, the dry biomass of the fruit and plants, and the $\mathrm{WUE}_{\mathrm{F}}$, whereas it had no effect on the number of fruits per plant and the weight of the fresh fruit. There was no interaction between the $\mathrm{EC}_{\mathrm{iw}}$ and $\mathrm{LF}$ in terms of yield parameters and $\mathrm{WUE}_{\mathrm{F}}$.

Effects of the $E C_{i w}$ and $L F$ on quality parameters. Hot pepper quality is a comprehensive index and consists of interactions among varying single quality attributes. The taste quality (TSS), nutritional quality (VC), storage quality $\left(\mathrm{F}_{\mathrm{n}}\right.$ and $\left.\mathrm{F}_{\mathrm{WC}}\right)$, and external quality $\left(\mathrm{F}_{\mathrm{L}}, \mathrm{F}_{\mathrm{MW}}\right.$, and $\left.\mathrm{F}_{\mathrm{SI}}\right)$ were all analyzed in this study. Table 2 shows fruit quality parameters using different levels of $\mathrm{EC}_{\mathrm{iw}}$ and LFs. The $\mathrm{EC}_{\mathrm{iw}}$ showed a marked influence on fruit quality parameters across the LFs. The TSS content in the $\mathrm{EC}_{\mathrm{iw}}$ of $2.7-7.0 \mathrm{dS} \cdot \mathrm{m}^{-1}$ increased significantly by $8.8 \%$ to $29.7 \%$ when compared with the $\mathrm{EC}_{\mathrm{iw}}$ of $0.9 \mathrm{dS} \cdot \mathrm{m}^{-1}$, whereas a significant increase in the $\mathrm{VC}$ content was only observed in the $\mathrm{EC}_{\mathrm{iw}}$ of $7.0 \mathrm{dS} \cdot \mathrm{m}^{-1}$. A higher $\mathrm{EC}_{\mathrm{iw}}$ led to a higher $\mathrm{F}_{\mathrm{n}}$ value. However, if the $\mathrm{EC}_{\mathrm{iw}}$ was increased from 0.9 to $7.0 \mathrm{dS} \cdot \mathrm{m}^{-1}$, the $\mathrm{F}_{\mathrm{WC}}$ decreased significantly from $92.83 \%$ to $89.87 \%$. Increases in the $\mathrm{EC}_{\mathrm{iw}}$ correspond to an increase in the $\mathrm{F}_{\mathrm{SI}}$, but to a reduction in the $\mathrm{F}_{\mathrm{L}}$ and $\mathrm{F}_{\mathrm{MW}}$.

Across the $\mathrm{EC}_{\mathrm{iw}}$, there were no significant differences in the $F_{L}, T S S$, and $F_{n}$ between the two LFs, whereas an increase in the LF led to an increase in the $\mathrm{VC}$ and $\mathrm{F}_{\mathrm{WC}}$, and a decrease in the $\mathrm{F}_{\mathrm{MW}}$ and $\mathrm{F}_{\mathrm{SI}}$. The $\mathrm{EC}_{\mathrm{iw}}$ and LF had no interactions in terms of the TSS, $\mathrm{VC}, \mathrm{F}_{\mathrm{n}}, \mathrm{F}_{\mathrm{WC}}$, and $\mathrm{F}_{\mathrm{MW}}$, whereas there were interactions with respect to the $\mathrm{F}_{\mathrm{L}}$ and $\mathrm{F}_{\mathrm{SI}}$.

Effects of the $E C_{i w}$ and $L F$ on the ion content in the fruit. Change in the $\mathrm{EC}_{\mathrm{iw}}$ showed no effect on the $\mathrm{Ca}^{2+}$ and $\mathrm{K}^{+}$contents of the fruit (Table 3). However, as the $\mathrm{EC}_{\mathrm{iw}}$ increased, the $\mathrm{Na}^{+}$content in the fruit increased, whereas the $\mathrm{K}^{+} / \mathrm{Na}^{+}$ratio decreased. Change in LF showed no significant differences in the ion content in the fruit.

Salinity response models and water stress caused by salinity. Figure 1 shows the $\mathrm{Y}_{\mathrm{r}}$ data plotted against the $\mathrm{EC}_{\mathrm{iw}}, \mathrm{EC}_{\mathrm{e}}$, and $E_{d w}$, respectively. Values of $Y_{r}$ data decreased as the $\mathrm{EC}_{\mathrm{iw}}, \mathrm{EC}_{\mathrm{e}}$, or $\mathrm{EC}_{\mathrm{dw}}$ increased, with these data falling into a curve regardless of the LFs. Figure 1 also shows the fitted threshold-slope linear model and sigmoidalshape model curves. Both models seem to accord reasonably well with the measured $\mathrm{Y}_{\mathrm{r}}$ data within our $\mathrm{EC}_{\mathrm{iw}}$ treatments, with the LF having no significant effect on these model parameters.

The relationship between the $Y_{r}$ and the $\mathrm{ET}_{\mathrm{r}}$ of the hot peppers is shown in Fig. 2. There was a significant $(P<0.001)$ linear correlation between the $\mathrm{Y}_{\mathrm{r}}$ and the $\mathrm{ET}_{\mathrm{r}}$ with a slope of $1.65\left(\mathrm{~K}_{\mathrm{y}}\right.$ value $)$ regardless of the LFs, indicating that hot peppers are highly sensitive to water stress caused by salinity.

The quantitative relationship between fruit quality parameters and the $E C_{e}$ and $E T_{r}$. Figure 3 shows the relationship between the fruit quality parameters of the hot peppers and the $\mathrm{EC}_{\mathrm{e}}$ across the LFs. The relative TSS and $F_{n}$ show a significant positive linear correlation with the $\mathrm{EC}_{\mathrm{e}}$ (Fig. 3A and B). A significant negative linear correlation was observed between the relative $\mathrm{F}_{\mathrm{WC}}, \mathrm{F}_{\mathrm{L}}, \mathrm{F}_{\mathrm{MW}}$, and the $\mathrm{EC}_{\mathrm{e}}$ (Fig. 3C-E). However, there was no significant $(P>0.05)$ correlation between the relative $\mathrm{F}_{\mathrm{SI}}$ and $\mathrm{VC}$ and the $\mathrm{EC}_{\mathrm{e}}$ (Fig. $3 \mathrm{~F}$ and G). The LF had no effect on the parameters of these correlations.

Figure 4 shows the relationship between the fruit quality parameters of the hot peppers and the $\mathrm{ET}_{\mathrm{r}}$ across the LFs. An increase in the $\mathrm{ET}_{\mathrm{r}}$ leads to a significant linear decrease in the relative TSS and $F_{n}$ (Fig. 4A and B), whereas there is a significant linear increase in the relative $\mathrm{F}_{\mathrm{W}}, \mathrm{F}_{\mathrm{L}}$, and $\mathrm{F}_{\mathrm{MW}}$ (Fig. $4 \mathrm{C}-\mathrm{E}$ ). No significant $(P>0.05)$ correlations were found between the relative $\mathrm{F}_{\mathrm{SI}}$ and $\mathrm{VC}$ and the $\mathrm{ET}_{\mathrm{r}}$ (Fig. 4F and G). The LF had no effect in terms of the parameters of these relationships.

The quantitative relationships between the ion content of the fruit and the $E C_{e}$ and $E T_{r}$. The relative $\mathrm{Na}^{+}$content in the fruit increased linearly with the $\mathrm{EC}_{\mathrm{e}}$ but decreased linearly with the $\mathrm{ET}_{\mathrm{r}}$ regardless of the LFs (Fig. 5A and C). Increases in the $\mathrm{EC}_{\mathrm{e}}$ led to a significant linear decrease in the relative $\mathrm{K}^{+} / \mathrm{Na}^{+}$(Fig. 5B), whereas it increased linearly as the $\mathrm{ET}_{\mathrm{r}}$ increased irrespective of the LFs (Fig. 5D). There was no correlation between the $\mathrm{K}^{+}$or $\mathrm{Ca}^{2+}$ content in the fruit and the $\mathrm{EC}_{\mathrm{e}}$ or $\mathrm{ET}_{\mathrm{r}}$ (figure not shown). 


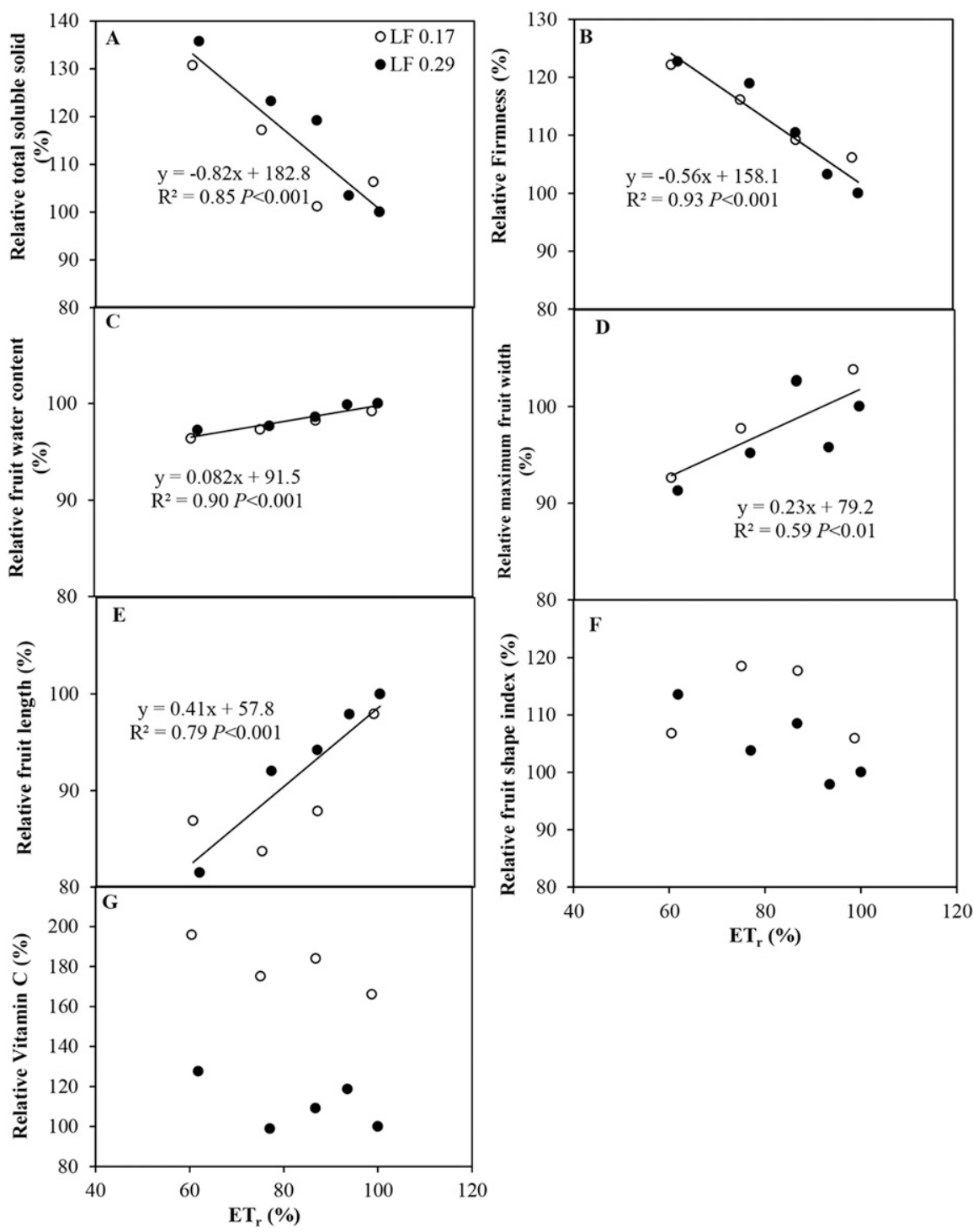

Fig. 4. Relationships between relative quality parameters [total soluble solid (A); firmness (B); fruit water content $(\mathbf{C})$; maximum fruit width $(\mathbf{D})$; fruit length $(\mathbf{E})$; fruit sharp index $(\mathbf{F})$ and Vitamin $\mathrm{C}(\mathbf{G})]$ and relative seasonal evapotranspiration $\left(\mathrm{ET}_{\mathrm{r}}\right)$ regardless of the leaching fractions $(\mathrm{LFs})$.

\section{Discussion and Conclusions}

Water is a crucial factor affecting the hot pepper yield and fruit quality. A salt-induced water deficit (as reflected by the high $\mathrm{K}_{\mathrm{y}}$ of 1.65 in Fig. 2) is one of the major constraints in the way of plant growth, inhibiting the crop yield. However, a water deficit caused by high salinity may also improve fruit quality (Adams and Ho, 2015; Chen et al., 2016; Rubio et al., 2009). The simultaneous control of yield and fruit quality is usually a challenge, however, as a result of the inverse relationship between yield and fruit quality (Wang et al., 2011).

The total fruit yield and dry biomass of the plants both decreased significantly as a result of an increase in the $\mathrm{EC}_{\mathrm{iw}}$ (Table 1). A reduction in the number of fruits per plant contributed nearly as much to a reduced total fruit yield as a result of salinity as did the weight of the fresh fruit (Table 1). The reduction in the weight of the fresh fruit through the $\mathrm{EC}_{\mathrm{iw}}$ was because of a reduction in the $\mathrm{F}_{\mathrm{WC}}$ rather than in the mean dry biomass of the fruit (Table 2, data for the mean dry biomass of the fruit are not shown). The reduction of the total fruit yield under saline irrigation could be explained as a saltinduced water deficit, the accumulation of $\mathrm{Na}^{+}$in plants and the inhibited uptake of $\mathrm{K}^{+}$ (Chen et al., 2016; Garcia-Legaz et al., 2005). These changes have an adverse effect on gas exchange and plant growth, in turn affecting yield. The $\mathrm{WUE}_{\mathrm{F}}$ of hot peppers was remarkably restricted by the $\mathrm{EC}_{\mathrm{iw}}$ because salinity reduces total fruit yield more than it reduced water loss.

A high yield, in conjunction with highquality fresh fruit, is crucial for increasing the economic benefits for farmers (Chen et al., 2016). In this study, except for the external quality (reflected as $\mathrm{F}_{\mathrm{L}}, \mathrm{F}_{\mathrm{MW}}$, and $\mathrm{F}_{\mathrm{SI}}$ ), the storage quality $\left(\mathrm{F}_{\mathrm{n}}\right.$ and $\left.\mathrm{F}_{\mathrm{WC}}\right)$, taste quality (TSS), and nutritional quality (VC) increased significantly with increased $\mathrm{EC}_{\mathrm{iw}}$. The lower $\psi_{\mathrm{S}}$ of soil water and consequently, the lower availability of soil water for the fruit caused by salinity leads to a reduction in cell size and intercellular volume and in turn reduce the $\mathrm{F}_{\mathrm{WC}}, \mathrm{F}_{\mathrm{L}}$, and $\mathrm{F}_{\mathrm{MW}}$. The $\mathrm{F}_{\mathrm{SI}}$ value was increased with the increase in the $\mathrm{EC}_{\mathrm{iw}}$ because salinity reduced the $F_{L}$ more than it reduced the $\mathrm{F}_{\mathrm{MW}}$ (Table 2). The decrease in the $\mathrm{F}_{\mathrm{WC}}$ might imply the occurrence of osmotic adjustment (Johnson et al., 2006). $F_{n}$ is one of the main attributes determining the storage capacity of fruits: a higher $F_{n}$ could reduce the mechanical damage and improve the storage durability of fruits (Flores et al., 2003). In this study, the $F_{n}$ increased significantly by $9.0 \%$ to $22.2 \%$ in the $\mathrm{EC}_{\mathrm{iw}}$ of 2.7-7.0 dS. $\mathrm{m}^{-1}$, compared with the $\mathrm{EC}_{\mathrm{iw}}$ of $0.9 \mathrm{dS} \cdot \mathrm{m}^{-1}$ across the LFs. The possible reasons are that 1) as a small fruit tends to have a high $F_{n}$, the increased cellular density due to the reduction in fruit size under saline treatment increases the $\mathrm{F}_{\mathrm{n}}$ (Wang et al., 2011); 2) the increased water stress caused by salinity during fruit enlargement and maturity enhances the $F_{n}$ (Chen et al., 2013; Patanè and Cosentino, 2010); and 3) Belakbir et al. (1998) showed that the $F_{n}$ in peppers is related to the level of $\mathrm{Ca}^{2+}$ in the fruit, and that salinity is able to reduce $F_{n}$ by reducing the availability of $\mathrm{Ca}^{2+}$ in the fruits. However, in this study, the $\mathrm{Ca}^{2+}$ in fruit was unaffected by salinity, indicating that the $\mathrm{Ca}^{2+}$ in the fruits is not the reason for the increased $F_{n}$ in saline irrigation. High $\mathrm{F}_{\mathrm{n}}$ and low $\mathrm{F}_{\mathrm{WC}}$ in salinity treatment indicate the fact that irrigation with saline water is able to improve the quality of fruit storage.

Unlike Navarro et al. (2010) and Rubio et al. (2009), who found that low levels of $\mathrm{EC}_{\mathrm{iw}}$ (less than $3 \mathrm{dS} \cdot \mathrm{m}^{-1}$ ) did not increase the TSS content in sweet peppers, in this study, the $\mathrm{EC}_{\mathrm{iw}}$ promoted the TSS content in hot peppers (Table 2). A reduced water uptake in plants irrigated using saline water leads to an increase in soluble concentrations and in turn increases the TSS content (Malash et al., 2008). The reduction of the $\mathrm{F}_{\mathrm{WC}}$ in hot pepper fruits undergoing salinity treatment (Table 2) might also have contributed to the increased TSS content.

A higher VC content was observed in hot pepper fruits (Vanderslice et al., 1990). VC is considered to be an important nutritional quality owing to its antioxidant characteristics (Wang et al., 2011). The VC content in the $\mathrm{EC}_{\mathrm{iw}}$ of $7.0 \mathrm{dS} \cdot \mathrm{m}^{-1}$, in this study, was increased significantly by $48.6 \%$, compared with the $\mathrm{EC}_{\mathrm{iw}}$ of $0.9 \mathrm{dS} \cdot \mathrm{m}^{-1}$ across the LFs. The possible reasons are that 1 ) the salinity reduced water uptake by roots, resulting in water stress (as reflected by $\mathrm{K}_{\mathrm{y}}$ in Fig. 2), consequently increasing the $\mathrm{VC}$ content (Patanè et al., 2011); and 2) the leaf area reduced by the salinity could increase the light intensity and duration, in turn, promoting the accumulation of $\mathrm{VC}$ (Chen et al., 2013; Wang et al., 2011).

To provide an important basis for salinity irrigation and management, the quantitative relationship between yield, fruit quality, fruit ion content, and $\mathrm{EC}_{\mathrm{e}}$ or $\mathrm{ET}_{\mathrm{r}}$ should be investigated. The response of a total yield of fresh hot peppers to salinity can be represented 

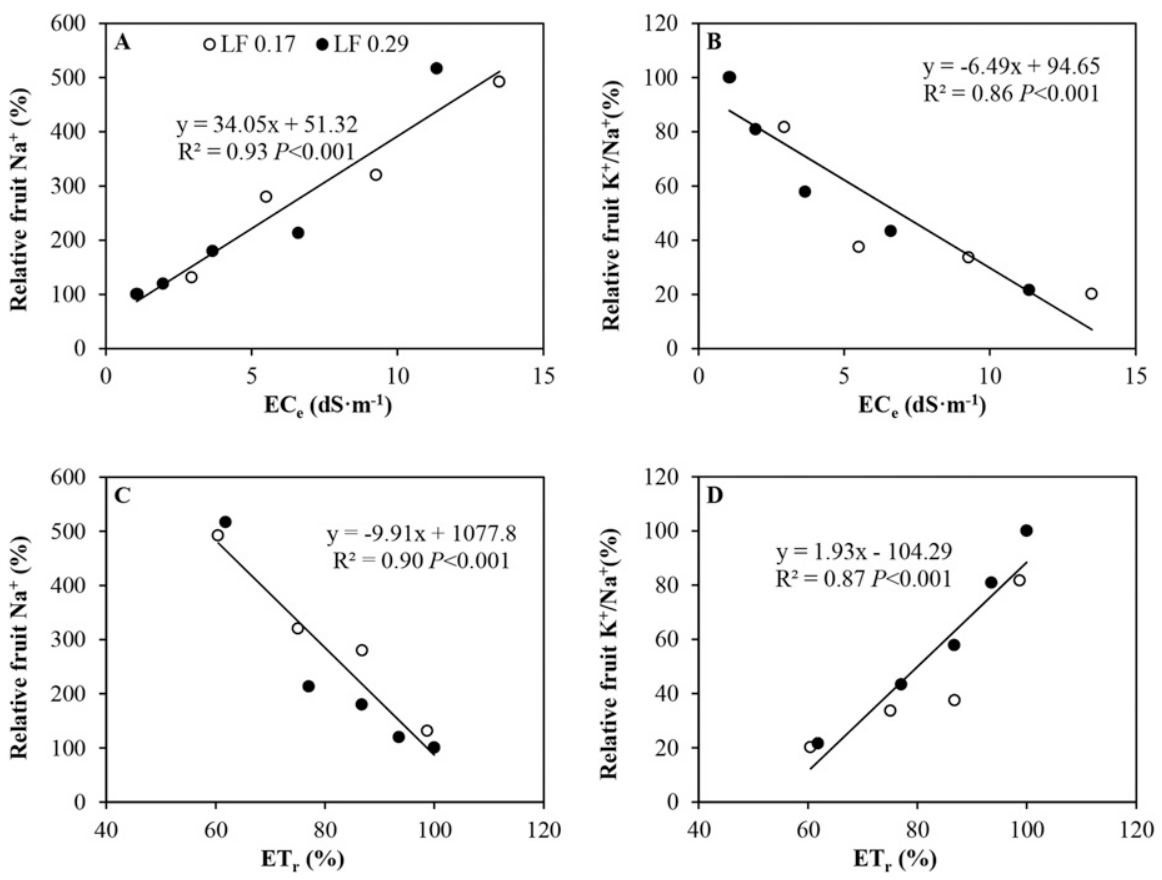

Fig. 5. Relationships between relative fruit ion content $\left(\mathrm{Na}^{+}\right.$and $\left.\mathrm{K}^{+} / \mathrm{Na}^{+}\right)$and the $\mathrm{EC}$ of soil saturated paste extract $\left(\mathrm{EC}_{\mathrm{e}} ; \mathbf{A}\right.$ and $\left.\mathbf{B}\right)$, and relative seasonal evapotranspiration $\left(\mathrm{ET}_{\mathrm{r}} ; \mathbf{C}\right.$ and $\left.\mathbf{D}\right)$; $\mathrm{LF}$ is the leaching fraction.

effectively by using a threshold-slope linear model or sigmoidal-shape model in terms of $\mathrm{EC}_{\mathrm{iw}}, \mathrm{EC}_{\mathrm{e}}$, or $\mathrm{EC}_{\mathrm{dw}}$ within our experimental range regardless of the LFs. The $b$ parameter for the threshold-slope linear model based on $\mathrm{EC}_{\mathrm{iw}}$ was $0.096(9.6 \%)$, which fell within the range of $8.4 \%$ to $11.7 \%$ as suggested by Chartzoulakis and Klapaki (2000), whereas the $\mathrm{EC}_{\mathrm{t}}$ was much lower than their 1.8. The $b$ and $\mathrm{EC}_{\mathrm{t}}$ parameters for the threshold-slope linear model based on $\mathrm{EC}_{\mathrm{e}}$ were 0.051 $(5.1 \%)$ and $1.1 \mathrm{dS} \cdot \mathrm{m}^{-1}$, respectively, i.e., lower than the $7.0 \%$ to $16.0 \%$ and $1.2-4.0$ $\mathrm{dS} \cdot \mathrm{m}^{-1}$ found in previous studies, as listed by Rameshwaran et al. (2016). The differences in the parameters across studies may be as a result of the varieties of pepper used, the irrigation method, soil fertilizer, climatic conditions, and the growth season (Chartzoulakis and Klapaki, 2000; Heidarpour et al., 2009; Rameshwaran et al., 2016). The $b$ and $s$ parameters for the thresholdslope linear model and sigmoidal-sharp model based on the $\mathrm{EC}_{\mathrm{dw}}$ were lower than those based on the $\mathrm{EC}_{\mathrm{iw}}$ and $\mathrm{EC}_{\mathrm{e}}$, whereas the $\mathrm{EC}_{\mathrm{dw} \text { o }}$ and $\mathrm{EC}_{\mathrm{dw} 50}$ were higher for the higher concentrations of $\mathrm{EC}_{\mathrm{dw}}$ than those of the $\mathrm{EC}_{\mathrm{iw}}$ and $\mathrm{EC}_{\mathrm{e}}$.

Many chemical reactions take place and are ultimately responsible for the high quality of hot peppers at the onset of fruit ripening. The relative TSS and $F_{n}$ were found to decrease linearly with the $\mathrm{ET}_{\mathrm{r}}$, which is in line with the findings of Chen et al. (2013) for tomatoes grown in greenhouse. No data for the $F_{W}, F_{L}$, and $F_{M W}$ were analyzed in their study; however. In this study, the relative $\mathrm{F}_{\mathrm{W}}$, $\mathrm{F}_{\mathrm{L}}$, and $\mathrm{F}_{\mathrm{MW}}$ decreased linearly with the $\mathrm{ET}_{\mathrm{r}}$ and increased linearly with the $\mathrm{EC}_{\mathrm{e}}$, because the $\mathrm{ET}_{\mathrm{r}}$ was reduced linearly with the $\mathrm{EC}_{\mathrm{e}}$.
Rubio et al. (2009) showed that $\mathrm{Ca}^{2+}$ was lower in the fruits of salinized plants than in the fruits of plants irrigated with salt-free water. The fruit $\mathrm{Ca}^{2+}$ and $\mathrm{K}^{+}$concentrations in this study were unaffected by the $\mathrm{EC}_{\mathrm{iw}}$, however, indicating that the uptake of mineral nutrition was not limited to the sufficient mineral nutrition (half strength Hoagland solution) supply in the irrigation water. Insufficient $\mathrm{Ca}^{2+}$ results in blossom end rot, a physiological disorder afflicting hot peppers that reduces the market yield and quality of the fruits (Chen et al., 2016; Rubio et al., 2009). No blossom end rot was observed in this study, which also reflected the fact that $\mathrm{Ca}^{2+}$ of the fruit was not limited. The $\mathrm{Na}^{+}$ concentration in the fruits increased as $\mathrm{EC}_{\mathrm{iw}}$ increased, in line with the findings of Azuma et al. (2010). A linear positive correlation between the relative $\mathrm{Na}^{+}$concentration in fruits and $\mathrm{EC}_{\mathrm{e}}$ and linear negative correlation between relative $\mathrm{K}^{+} / \mathrm{Na}^{+}$ratio and $\mathrm{EC}_{\mathrm{e}}$ suggest that $\mathrm{Na}^{+}$caused salt toxicity including an ion imbalance and water deficit in the tissue of the fruit (Azuma et al., 2010).

An increase in the LF was observed to lead to an increase in the total fruit yield because of an increase in the total dry biomass of the fruit, whereas the LF had no effects on the number of fruits per plant and the weight of the fresh fruit (Table 1). Neither did the LF affect the total fruit yield, number of fruits per plant, and weight of the fresh fruit before the fifth harvesting, indicating that the LF needs sufficient time to affect the total fruit yield. The $\mathrm{WUE}_{\mathrm{F}}$ of hot peppers was high in the high LF because it increased the total fruit yield more than it increased the seasonal ET. No significant differences in the TSS, $F_{n}$, and $F_{L}$ were observed across the two
LFs, whereas an increase in the LF was found to lead to a significant decrease in the $\mathrm{F}_{\mathrm{MW}}$ and $\mathrm{F}_{\mathrm{SI}}$, whereas the $\mathrm{F}_{\mathrm{WC}}$ and $\mathrm{VC}$ content increased. The increased $\mathrm{F}_{\mathrm{SI}}$ in the lower LF was mainly as a result of a greater $F_{\mathrm{MW}}$. The low $\mathrm{F}_{\mathrm{WC}}$ in the low LF would indicate that a low LF could improve the storage quality of the fruit. However, the mechanism of a high content of VC in the high LF remains elusive and merits further investigation. The LF had no effect in terms of the parameters using the threshold-slope linear and sigmoidal-sharp models as well as the $\mathrm{K}_{\mathrm{y}}$ value using the yield-moisture stress relationship (Fig. 2) and the correlation between quality parameters and $\mathrm{EC}_{\mathrm{e}}$ or $\mathrm{ET}_{\mathrm{r}}$, indicating that the $\mathrm{LF}$ is not the main factor governing the difference in the parameter values for models across studies, neither did the LF effect on the correlation between the ion content of the fruit and the $\mathrm{EC}_{\mathrm{e}}$ or $\mathrm{ET}_{\mathrm{r}}$.

In summary, the threshold-slope linear and sigmoidal-sharp models both suited the measured $\mathrm{Y}_{\mathrm{r}}$ reasonably well within our $\mathrm{EC}_{\mathrm{iw}}$ range. The relative TSS and $F_{n}$ increased linearly with the $\mathrm{EC}_{\mathrm{e}}$ and decreased linearly with the $\mathrm{ET}_{\mathrm{r}}$, whereas the relative $\mathrm{F}_{\mathrm{W}}, \mathrm{F}_{\mathrm{L}}$, and $\mathrm{F}_{\mathrm{MW}}$ decreased linearly with the $\mathrm{EC}_{\mathrm{e}}$ and increased linearly with the $\mathrm{ET}_{\mathrm{r}}$. The relative $\mathrm{Na}^{+}$concentration in the fruit increased linearly, whereas the relative fruit $\mathrm{K}^{+} / \mathrm{Na}^{+}$ ratio decreased linearly with an increased $\mathrm{EC}_{\mathrm{e}}$. Interestingly, the LF had no effect on these correlations with respect to fruit yield, quality, ion content, and $\mathrm{EC}_{\mathrm{e}}$ or $\mathrm{ET}_{\mathrm{r}}$.

The total fruit yield and $\mathrm{WUE}_{\mathrm{F}}$ decreased significantly as the $\mathrm{EC}_{\mathrm{iw}}$ increased. Increased salinity reduced the external quality of hot peppers, whereas improved the taste, nutritional and storage quality of the hot peppers, and led to a higher accumulation of $\mathrm{Na}^{+}$in the fruit. High LF increased the total fruit yield, WUE $_{\mathrm{F}}$, and nutritional quality but decreased in the $\mathrm{F}_{\mathrm{MW}}$ and $\mathrm{F}_{\mathrm{SI}}$. Therefore, it is suggested that high LF can be applied to obtain high yield and better-quality fruit when hot peppers are irrigated with water having a high level of saline content.

\section{Literature Cited}

Adams, P. and L.C. Ho. 2015. Effects of constant and fluctuating salinity on the yield, quality and calcium status of tomatoes. J. Hort. Sci. 64:725-732.

AOAC. 1984. Vitamin C (Ascorbic Acid) in Vitamin preparations and Juices: 2, 6-Dichloroindophenol titrimetric method. Assn. Offic. Anal. Chemists, Washington, DC.

Azuma, R., N. Ito, N. Nakayama, R. Suwa, N.T. Nguyen, J.Á. Larrinaga-Mayoral, M. Esaka, H. Fujiyama, and H. Saneoka. 2010. Fruits are more sensitive to salinity than leaves and stems in pepper plants (Capsicum annuиm L.). Sci. Hort. 125:171-178.

Belakbir, A., J.M. Ruiz, and L. Romero. 1998 Yield and fruit quality of pepper (Capsicum annuи $\mathrm{L}$.) in response to bioregulators. HortScience 33:85-87.

Ben-Gal, A., E. Ityel, L. Dudley, S. Cohen, U. Yermiyahu, E. Presnov, L. Zigmond, and U. Shani. 2008. Effect of irrigation water salinity on transpiration and on leaching requirements: 
A case study for bell peppers. Agr. Water Mgt. 95:587-597.

Chartzoulakis, K. and G. Klapaki. 2000. Response of two greenhouse pepper hybrids to $\mathrm{NaCl}$ salinity during different growth stages. Sci. Hort. 86:247-260.

Chen, J.L., S.Z. Kang, T.S. Du, R.J. Qiu, P. Guo, and R.Q. Chen. 2013. Quantitative response of greenhouse tomato yield and quality to water deficit at different growth stages. Agr. Water Mgt. 129:152-162.

Chen, S., Z.Y. Zhang, Z.C. Wang, X.P. Guo, M.H. Liu, Y.A. Hamoud, J.C. Zheng, and R.J. Qiu. 2016. Effects of uneven vertical distribution of soil salinity under a buried straw layer on the growth, fruit yield, and fruit quality of tomato plants. Sci. Hort. 203:131-142.

Colla, G., Y. Rouphael, M. Cardarelli, D. Massa, A. Salerno, and E. Rea. 2006. Yield, fruit quality and mineral composition of grafted melon plants grown under saline conditions. J. Hort. Sci. Biotechnol. 81:146-152.

Doorenbos, J. and A.H. Kassam. 1979. Yield response to water, FAO Irrigation and Drainage Paper, No 33. FAO, Roma.

Dudley, L.M., A. Ben-Gal, and U. Shani. 2008. Influence of plant, soil, and water on the leaching fraction. Vadose Zone J. 7:420-425.

Flores, P., J.M. Navarro, M. Carvajal, A. Cerda, and V. Martínez. 2003. Tomato yield and quality as affected by nitrogen source and salinity. Agronomie 23:249-256.

Garcia-Legaz, M.F., E. López Gómez, J. Mataix Beneyto, A. Torrecillas, and M.J. SánchezBlanco. 2005. Effects of salinity and rootstock on growth, water relations, nutrition and gas exchange of loquat. J. Hort. Sci. Biotechnol. 80:199-203.

Gough, C. and G.E. Hobson. 2015. A comparison of the productivity, quality, shelf-life characteristics and consumer reaction to the crop from cherry tomato plants grown at different levels of salinity. J. Hort. Sci. 65:431-439.

Grattan, S.R., C. Shennan, D. May, B. Roberts, M. Borin, and M. Sattin. 1994. Utilizing saline drainage water to supplement irrigation water requirements of tomato in a rotation with cotton. Proc. III Congr. European Soc. Agron. Padova Univ., Abano-Padova, Italy.

Heeg, C., C. Kruse, R. Jost, M. Gutensohn, T. Ruppert, M. Wirtz, and R. Hell. 2008. Analysis of the Arabidopsis O-acetylserine (thiol) lyase gene family demonstrates compartment-specific differences in the regulation of cysteine synthesis. Plant Cell 20:168-185.

Heidarpour, M., B. Mostafazadeh Fard, A. Arzani, A. Aghakhani, and M. Feizi. 2009. Effects of irrigation water salinity and leaching fraction on yield and evapotranspiration in spring wheat. Commun. Soil Sci. Plant Anal. 40:2521-2535.

Johnson, R.W., M.A. Dixon, and D.R. Lee. 2006. Water relations of the tomato during fruit growth. Plant Cell Environ. 15:947-953.

Kiremit, M.S. and H. Arslan. 2016. Effects of irrigation water salinity on drainage water salinity, evapotranspiration and other leek $(\mathrm{Al}$ lium porrum L.) plant parameters. Sci. Hort. 201:211-217.

Maas, E.V. and G.J. Hoffman. 1977. Crop salt tolerance-current assessment. J. Irrig. Drain. Div. 103:115-134.

Malash, N.M., T.J. Flowers, and R. Ragab. 2008. Effect of irrigation methods, management and salinity of irrigation water on tomato yield, soil moisture and salinity distribution. Irrig. Sci. 26:313-323.

Munns, R. 2002. Comparative physiology of salt and water stress. Plant Cell Environ. 25:239-250.

Navarro, J.M., M.A. Botella, and V. Martinez. 1999. Yield and fruit quality of melon plants grown under saline conditions in relation to phosphate and calcium nutrition. J. Hort. Sci. Biotechnol. 74:573-578.

Navarro, J.M., C. Garrido, M. Carvajal, and V. Martinez. 2002. Yield and fruit quality of pepper plants under sulphate and chloride salinity. J. Hort. Sci. Biotechnol. 77:52-57.

Navarro, J.M., C. Garrido, P. Flores, and V. Martínez. 2010. The effect of salinity on yield and fruit quality of pepper grown in perlite. Span. J. Agr. Res. 8:142-150.
Patanè, C. and S.L. Cosentino. 2010. Effects of soil water deficit on yield and quality of processing tomato under a Mediterranean climate. Agr. Water Mgt. 97:131-138.

Patanè, C., S. Tringali, and O. Sortino. 2011. Effects of deficit irrigation on biomass, yield, water productivity and fruit quality of processing tomato under semi-arid Mediterranean climate conditions. Sci. Hort. 129:590-596.

Patil, V.C., K.A. Al-Gaadi, M.A. Wahb-Allah, A.M. Saleh, S.A. Marey, M.S. Samdani, and M.E. Abbas. 2014. Use of saline water for greenhouse bell pepper (Capsicum annuum) production. Amer. J. Agr. Biol. Sci. 9:208217 .

Plaut, Z. and C.E. Yehezkel. 2004. How do salinity and water stress affect transport of water, assimilates and ions to tomato fruits? Physiol. Plant. 122:429-442.

Rameshwaran, P., A. Tepe, A. Yazar, and R. Ragab. 2016. Effects of drip-irrigation regimes with saline water on pepper productivity and soil salinity under greenhouse conditions. Sci. Hort. 199:114-123.

Rubio, J.S., F. García-Sánchez, F. Rubio, and V. Martínez. 2009. Yield, blossom-end rot incidence, and fruit quality in pepper plants under moderate salinity are affected by $\mathrm{K}^{+}$and and $\mathrm{Ca}^{2+}$ fertilization. Sci. Hort. 119:79-87.

Stewart, J.I. and R.M. Hagan. 1973. Functions to predict effects of crop water deficits. J. Irrig. Drain. Div. 99:421-439.

Van Genuchten, M.T. and G.J. Hoffman. 1984. Analysis of crop production. In: I. Shainberg and J. Shalhevet (eds.). Soil salinity under irrigation. Springer, New York, NY.

Vanderslice, J.T., D.J. Higgs, J.M. Hayes, and G. Block. 1990. Ascorbic acid and dehydroascorbic acid content of foods-as-eaten. J. Food Compos. Anal. 3:105-118.

Wang, F., S.Z. Kang, T.S. Du, F.S. Li, and R.J. Qiu. 2011. Determination of comprehensive quality index for tomato and its response to different irrigation treatments. Agr. Water Mgt. 98:12281238 . 